\title{
The Weight Strategy of Ideological and Political Education Discourse in the Media Age
}

\author{
Li Zhaoyuan
}

Shan Dong Ying Cai University, Shandong, Jinan, 250000

Keywords: self-media era; ideological and political education in colleges and universities; discourse power

\begin{abstract}
With the continuous development of Internet technology and modern information technology, the advent of the era of self-media has been promoted. Since the media in the process of disseminating information, liberalization, personalization and popularization have made it widely used. At the same time, since the speed of media dissemination is fast and the operation is relatively simple, the rapid development of the self-media has been promoted. In the course of ideological and political education in colleges and universities, discourse is an important means of education. To grasp the right of discourse is beneficial to the work of ideological and political education. The first part of this paper is of great significance and profound influence on the ideological and political education of colleges and universities from the arrival of the media era. The second part analyzes the problems encountered in ideological and political education in colleges and universities in the era of self-media. Finally, in order to enhance the discourse ability of ideological and political education and realize the ideological function, specific measures are put forward.
\end{abstract}

\section{The Significance of the Media Era to the Ideological and Political Education in Colleges and Universities}

The emergence of things has the influence of positive and negative two aspects. In the modern economy, the development mode of self media mainly, the wide and free nature of the media information dissemination way, causes the students' values and thinking ways to be easily distorted and deviated from the socialist core values, which brings new ideas to the ideological and political education of the school. Challenges and opportunities. On the one hand, schools should be based on the popularity of modern Internet mobile devices in the students and the students' participation in network activities and high attention. The school can establish the public number or official account of the school on the APP with high activity and attract students to participate in the school to carry forward the socialist spiritual civilization and core price. The activities of values, change the traditional way of classroom communication, change from the media to the media era, attract students to participate in the activities of the socialist spiritual civilization and core values, communicate with the students in a relaxed and pleasant atmosphere, and make correct statements in time for the bad information on the network. Using the Internet to help and reduce students' sense of confusion in the information age. On the other hand, the timeliness and transparency of information in the era of media provides a more convenient and independent platform for the ideological and political education of the school. The two-way and timely interaction between students and teachers can be realized by mobile phones. The educational activities of the school are not restricted by space. For example, in the official forum of the school, an open invitation letter is issued on the core values of socialism and a questionnaire on mobile phone after class is set up to see whether the classroom construction can help students resist the invasion of bad information, improve the sense of social responsibility, and deepen the understanding of the core value of social justice. 


\section{Problems of Ideological and Political Education in Colleges and Universities in the Media Age}

In the first place, the popularization of modern network technology has changed the channel for students to learn information. When students go home to write homework or do exercises, they find problems, and can directly use the Baidu or the learning and mutual assistance APP on the mobile network equipment to get a variety of problem solving methods, even a lot of exercise books. The square has the analytic two-dimensional code to use the real person explanation. Teachers in traditional education mode are important channels to get information. The situation has been broken through, and students' dependence on teachers has gradually decreased. And the answers to the network often solve the problems that students are learning in a timely manner. Secondly, the Internet has a wide range of knowledge, and most of the teachers' lesson preparation is by doing a large number of test points for the analysis of the exam or referring to the teaching cases in the past years, and the popularization of the network technology makes the breadth of knowledge not limited to the paper resources simply, and the teachers need to learn more widely to solve the students' continuous development. The new problem, the authority of teachers is challenged more, and more efforts should be made to enrich their knowledge reserves. Finally, on the Internet, the students can see the lecture video of many excellent teachers in the world, and more and more network classes have developed rapidly. Many students have looked into the classroom on the Internet and questioned the teaching methods of the teachers in the class, and the traditional information between teachers and students in the media era is not equal. The potential is being gradually broken. To sum up, in the new media age with convenient resources, ideological and political teachers should strengthen their comprehensive strength and make good use of new media to enhance teachers' authority.

First of all, the original intention of the new media network era is to make information sharing and acquisition more timely and convenient. On the other hand, it is to meet the requirements of modern economic development. In addition, in recent years, the construction of socialist democracy in China has been continuously promoted and perfected, and the environmental construction of the network tends to be more open, and the acquisition of resources in China can basically be synchronized with the world. The widespread popularity of mobile network equipment in students' learning life makes WeChat, QQ and other self media APP become the common platform for students to obtain information and express their speech. Everyone can become "keyboard man" and "microphone". The values of our society and the period of liberation have obtained unprecedented development, showing a lot of development. The trend of meta and globalization. This also makes some Western bad liberalist ideas spread to China through the network. On the network, the negative news, false news and scientific analysis of the socialist market economy are becoming more and more contaminated by the soil of the network. This information is easily acquired by students from the Internet, and it is easy to produce negative impressions of the motherland. This requires the modern ideological and political teachers to maintain the political sensitivity and change the past cramming style of the rigid teaching method, in the face of the increasingly diversified values to help students to distinguish and distinguish, to establish a correct socialist values.

The development of modern economy has promoted the continuous innovation and development of mobile network equipment and Internet technology. The label "low head" of modern people has become more and more deep, becoming a widespread act. This is mainly due to the more portable and fine differentiated information APP of mobile network devices, which makes information acquisition more pertinent and timely and the application technology of Internet technology is more sophisticated in mobile network devices, making people more dependent on mobile network devices. At present, people get information from friends circle on WeChat and share their stories become "point praise party". The information on hot spots on micro-blog becomes the "keyboard man" and "forwarding party", and the sharing and autonomy of information become more frequent. Everyone often thinks that the network is the virtual world, the information is wide open, it does not 
speak with its own real name, and the ability to restrain the moral is gradually reduced. The consciousness of personal freedom is flooded with the network. According to the survey report of the Internet Information Center in China, the average time of Internet access in China is about 3 hours a day, and it has occupied most of the rest time of our country. This is also an important reason for the formation of bad symptoms such as insomnia in our country. The students in our country are in the stage of cultivating "three views" and the transformation of life. They are attracted by the network and are attacked by FRET free information. The physical and mental health and values are easily impacted.

\section{Ideological and Political Educators Enhance the Right to Speak in the Media Age}

Ideological and political education workers in Colleges and universities should give full play to their leading role and improve their speaking ability when carrying out ideological and political education activities. On the one hand, ideological educators can use the self media platform to carry out ideological and political education, build a cultural form of principle and rational, guide students to judge what is a mature network environment, enhance the students' self-defense ability, and social analysis ability. At the same time, educators should combine the actual situation of the students and their own experience and skills to enhance the vitality and appeal of the discourse in the course of Ideological and educational activities, and create a vital education environment for the students. On the other hand, the users of Ideological and political education discourse are ideological educators, so in the era of self media, ideological educators should make full use of self media to carry out basic network learning, enhance the ability to use the technology from the media and improve the level of network knowledge. At the same time, ideological educators should take the initiative to pay attention to social affairs and current affairs and politics, and to combine the focus of society and so on to carry out some theme class meetings, enrich the content of current affairs, and reach a consensus on social problems. Educators should also receive regular training in network knowledge, improve their educational ability, broaden the knowledge of education, psychology, and so on. With the help of WeChat, micro-blog and other self media, the students can communicate with them and enhance their ability to interact with students. In addition, educators should learn from other people's excellent educational methods and draw lessons from them to improve their educational level and guarantee the right to speak.

On the one hand, in the face of the era of self media, ideological and political educators must strengthen their own ideological and moral construction and spiritual civilization construction, improve cultural cultivation and the level of scientific and technological use, and enhance their comprehensive strength. Educators should strengthen the research on self media technology, and use WeChat, micro-blog and other self media platforms to build their own open web courses. And publish positive energy information on their own platform, play the cohesive function of ideology, and closely link them with students. At the same time, teachers should also communicate and interact with students, master the students' learning state, realize the guiding function of ideology, and improve their ideological and moral level and spiritual civilization level. In carrying out classroom activities, we use self media to innovate teaching contents and adopt some teaching methods that are advancing with the times, such as heuristic teaching methods. On the other hand, the credibility is an important asset of the ideological and educational work in Colleges and universities. It can fully reflect the credibility of the ideological and educational workers, influence the strength, and the authority of the discourse. Ideological educators must build their own personality charm, academic level, ideological cultivation, professional knowledge, improve their comprehensive quality in an all-round way, and strive to strengthen their own construction in order to grasp the right to speak. Therefore, educators should enhance their own quality and enhance their credibility in Ideological and political education activities.

On the one hand, the ideological educators should carry out the education content of the students by the self media platform. In the daily life of the students, the rules and regulations of the school are melted into the students' daily life, and the students' ability to think rationally and solve problems is cultivated and the rational judgment is improved. Ideological education should innovate 
and develop discourse ability, grasp the right to speak and improve the influence of discourse. On the other hand, the rapid development of the media era has brought some negative negative network information in broadening the students' vision, which is very bad for the healthy development of the students' body and mind. Therefore, students should consciously improve the ability of screening information, strengthen their own ideological and moral construction and spiritual civilization construction, and comprehensively resist the information of garbage, and avoid the infringement of network information. Therefore, in the era of self media, ideological and political educators should enhance their rational thinking ability, and at the same time, improve their information processing ability.

With the development of information technology, the application of media has become more and more extensive, and its influence on society has been gradually strengthened. In this case, many traditional media and government related institutions have conformed to the development trend of the times, set up their own media platform, try to grasp the time of the right to speak, and improve their credibility. In the face of this situation, colleges and universities in China should keep high attention to the self media platform, enhance the sensitivity of self media judgment and use, and establish a healthy and active self media platform, enhance the interaction with students, and understand the students' learning and daily life. At the same time, the mainstream culture of consciousness is disseminated to students in a natural way, giving play to the role of mainstream consciousness. In the establishment of the media platform, colleges and universities should combine the ideological and political educators, the party organization, the student department and other key forces to enhance their level of interaction and cooperation, grasp the discourse power of Ideological and political education, and jointly promote the spread and development of the mainstream consciousness culture. At the same time, all teachers and students should jointly safeguard the daily operation of the school media platform and create a scientific and effective self media platform. We also use the media platform to release positive energy information, play the role of public opinion, carry out student activities, and promote the all-round development of students. Therefore, the establishment of an effective self media platform in Colleges and universities is beneficial to grasp the law of the development of social ideology, play the role of ideology, promote the development of the social mainstream consciousness culture, strengthen the cohesiveness, centripetal force and creativity of the socialist ideology in China.

\section{Conclusion}

The continuous development of modern information technology has promoted the advent of the era of self media. In the era of media, the channels and ways of people to receive information and communication have become more convenient, increasing the speed of communication of social information and drawing the distance between people. Ideological and political education is the main teaching content of colleges and universities. Since the arrival of the media, it provides some innovative teaching methods for the ideological and political education activities in Colleges and universities, which has brought many opportunities for education. At the present stage, there are some problems in the discourse power of Ideological and political education in China's colleges and universities, and the authority has been challenged. However, with the continuous reform and improvement, the discourse power of Ideological and political education will be affirmed, and it will contribute to the development of the socialist mainstream consciousness in China.

\section{Acknowledgment}

Fund Project: a special research project on Ideological and political education in the research program of Humanities and Social Sciences in Shandong Province in 2016: the study number J16ZC119 of the remolding of the discourse right of Ideological and political education in Colleges and universities in the context of "ideology" 


\section{References}

[1] Nie D, Marxism S O, University H. Analysis of the Effectiveness of the Discourse Power of Ideological and Political Education[J]. Journal of the Party School of Shengli Oilfield, 2016.

[2] Zhou C S. Rhetorical Strategies on Discourses of Ideological and Political Education in the Carnivalized Context of We- media[J]. Journal of Qiqihar University, 2016.

[3] Liang Q, Sun Y, Chen W. The Functions and Features of the Ideological and Political Education Discourse System Under the Environment of New Media[J]. Theory Research, 2017.

[4] Sun M. An Analysis of the Trend of the Army Ideological and Political Education Discourse from the New Media Development Perspective[J]. Journal of Chinese Peoples Armed Police Force Academy, 2016.

[5] Li L, Zhang H, Management S O. Three Key Points in Online Ideological and Political Education Discourse Power[J]. Journal of College Advisor, 2017.

[6] Jiang Z H. The Right of Discourse in Ideological and Political Education under the Background of "Internet + " and Its Realization[J]. Journal of Henan Judicial Police Vocational College, 2017. 